\title{
EVALUASI PENGARUH FAKTOR IKLIM PADA PEMBENTUKAN RANGKUM BUNGA DAN POLONG Indigofera zollingeriana
}

\author{
Nur Rochmah Kumalasari, Cathleya Rosadi, Luki Abdullah \\ Departemen Ilmu Nutrisi dan Teknologi Pakan Fakultas Peternakan, Institut Pertanian Bogor
}

\begin{abstract}
ABSTRAK
Faktor lingkungan dapat mempengaruhi produktivitas legum baik hijauan maupun bibit Indigofera. Penelitian ini bertujuan untuk mengevaluasi pengaruh faktor lingkungan pada pembentukan rangkum bunga dan polong Indigofera. Tanaman Indigofera mulai ditanam pada bulan April 2016 kemudian diamati pertumbuhan bunga dan polong mulai 28 Agustus - 31 Oktober 2016. Tanaman dikelompokkan dengan jarak antar tanaman adalah 1 x 1,5 m; 1,5 x 1,5 m dan 2 × 1,5 m. Parameter yang diukur adalah jumlah rangkum bunga dan jumlah polong. Faktor iklim yang dievaluasi adalah suhu, kelembaban, curah hujan, lama penyinaran, dankecepatanangin rata-rata selama masa penanaman. Data iklimdiambildari data BMKG 2016-2017. Data yang diperoleh dianalisis Analysis of Variance Matrix Unbalanced untuk mengetahui pengaruh faktor lingkungan terhadap rangkum bunga dan jumlah polong. Analisis menggunakan software statistik R 3.3.2. Dari penelitian ini dapat diambil kesimpulan bahwa faktor lingkungan mempengaruhi yang dapat mempengaruhi pembentukan rangkum bunga Indigofera adalah lama waktu penyinaran matahari, sedangkan pembentukan polong cenderung dipengaruhi kecepatan angin rata-rata.
\end{abstract}

Kata kunci: Indigofera zollingeriana, iklim, rangkum bunga, polong

\section{PENDAHULUAN}

Indigofera zollingeriana saat ini tengah menjadi salah satu tanaman legum yang dikembangkan secara nasional untuk penyediaan hijauan pakan ternak. Indigofera dapat mulai dipanen pada umur 38-88 hari setelah tanam (Abdullah dan Suharlina, 2010), dengan interval defoliasi antara 35-60 hari. Pada interval defoliasi 6o hari, Indigofera dapat mencapai produksi hijauan sebesar 51 ton ha/th (Abdullah 2010). Hijauan Indigofera memiliki kualitas yang tinggi dengan kandungan protein kasar dapat mencapai 20,4727,83\% (Abdullah, 2010) dengan produksi bahan kering sebesar 1,45-5,410 kg/ha/panen (Kumalasari et al, 2017; Abdullah dan Suharlina, 2010).

Indigofera zollingeriana sebagai tanaman leguminosa sangat potensial sebagai sumber hijauan pakan yang secara agronomis mudah dikembangkan melalui benih (Abdullah, 2014). Benih Indigofera yang beredar saat ini tersedia dalam bentuk biji dan bibit dengan harga biji mencapai Rp 500.000-1.000.000/ kg sedangkan bibit berkisar Rp 2.000-3.00o/bibit. Produksi biji bersertifikat saat ini telah diperoleh Laboratorium Agrostologi Departemen Ilmu Nutrisi dan Teknologi Pakan, Fakultas Peternakan IPB dari Kementrian Pertanian pada bulan Mei 2017. Produktivitas dan kualitas Indigofera yang tinggi sangat menarik minat petani/peternak untuk dapat membudidayakan Indigofera di areal pertaniannya sehingga meningkatkan jumlah permintaan akan benih Indigofera.

Peningkatan kebutuhan benih Indigofera ini memerlukan efisiensi dalam produksi benih Indigofera untuk dapat memperoleh produksi benih yang optimal. Produksi biji Indigofera dapat dipengaruhi oleh waktu panen, jumlah bunga dan jumlah polong (Jahan et $a l, 2013)$. Sedangkan lama periode pembungaan dan keragaman karakteristik dalam kualitas benih banyak dipengaruhi oleh curah hujan dan suhu (Łabuda dan Brodaczewska, 2007; Herrera et al, 2008). Peningkatan suhu dapat mempengaruhi kematangan dan sebaran benih tumbuhan tertentu (Buechlinget $a l$, 2016) sedangkan curah hujan dapat menurunkan produksi benih (Kumar et al, 2009).

Penelitian ini bertujuan untuk mengevaluasi pengaruh faktor lingkungan pada pembentukan rangkum bunga dan polong Indigofera. Faktor lingkungan yang diukur adalah suhu, kelembaban, curah hujan, lama penyinaran, dan kecepatan angin selama masa penanaman.

\section{MATERI DAN METODE}

Penelitian ini dilaksanakan pada bulan April 2016 sampai April 2017 di Laboratorium Agrostologi Fakultas Peternakan Institut Pertanian Bogor, Kabupaten Bogor, Jawa Barat. Bogor terletak di antara $106^{\circ} 43^{\prime} 30$ "BT - $106^{\circ} 51^{\prime}$ Oo"BT dan 30'30"LS - $6^{\circ} 41^{\prime} \mathrm{Oo}$ "LS serta mempunyai ketinggian terbawah rata-rata 190 meter.Tanaman Indigofera mulai 
ditanam pada bulan April 2016 kemudian diamati pertumbuhan bunga dan polong mulai 28 Agustus 31 Oktober 2016. Tanaman dikelompokkan dengan jarak antar tanaman adalah 1 x 1,5 m; 1,5 x 1,5 m dan $2 \times 1,5 \mathrm{~m}$. Parameter yang diukur adalah jumlah rangkum bunga dan jumlah polong. Faktor iklim yang dievaluasi adalah suhu, kelembaban, curah hujan, lama penyinaran, dan kecepatan angin rata-rata selama masa penanaman. Data iklim diambil dari data BMKG 2016-2017.

Data yang diperoleh dianalisis Analysis of Variance Matrix Unbalanced untuk mengetahui pengaruh factor lingkungan terhadap rangkum bunga dan jumlah polong. Analisis menggunakan software statistik $\mathrm{R}$ 3.3.2.

\section{HASIL DAN PEMBAHASAN}

\section{Keadaan Umum}

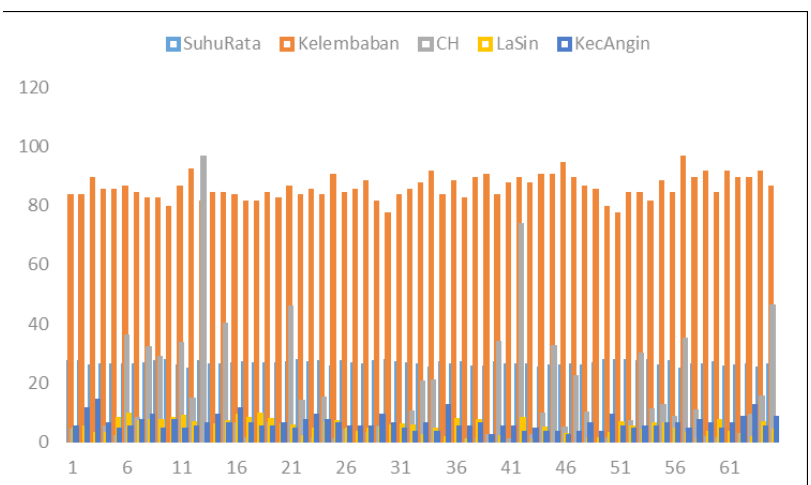

Gambar 1. Rata-Rata Suhu, Kelembaban, Curah Hujan, Lama Penyinaran dan Kecepatan Agin Selama Penelitian

Pengamatan bunga dan polong dilakukan pada akhir bulan September hingga November 2016 dengan curah hujan $768 \mathrm{~mm}$, kelembaban berkisar antara $77-92 \%$, suhu rata-rata $26,1^{\circ} \mathrm{C}$, dan lama penyinaran matahari berkisar antara 0,3 hingga 9,3 jam per hari. Keragaman data lingkungan terjadi karena pada bulan pengamatan ini merupakan masa transisi antara musim kemarau memasuki musim penghujan yang ditandai dengan meningkatnya jumlah hari hujan.

\section{Pengaruh Lingkungan pada Rangkum Bunga}

Pembentukan rangkum bunga merupakan salah satu fase penting dalam pertumbuhan tanaman, yang menandai masuknya tanaman ke dalam fase generatif (Purcell et al, 2014). Masa awal berbunga tanaman Indigofera cukup beragam antar individu yang ditanam dalam penelitian ini, mulai dari 64 sampai 138 hari setelah tanam.

Analisis data dilakukan pada hasil pengamatan sejak hari pertama muncul rangkum bunga (28 Agustus 2016) hingga 2 bulan. Analisis data yang dilakukan menunjukkan bahwa pertambahan rangkum bunga dipengaruhi oleh lama penyinaran matahari selama masa pembungaan (Tabel 1). Lama penyinaran selama pengamatan sangat beragam, mulai dari o,3 hingga 9,3 jam. Menurut Villacampa et al (2009), setiap tanaman legum memiliki ekspresi dan tahapan yang berbeda dalam merespon lama penyinaran.

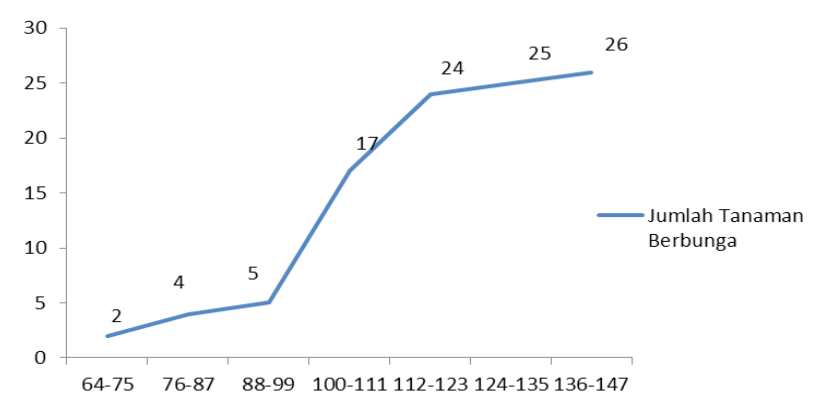

Gambar 2. Pertambahan Jumlah Tanaman Berbunga Selama Pengamatan

Tabel 1. Uji Pengaruh Lingkungan pada Pembentukan Jumlah Rangkum Bunga

\begin{tabular}{|c|c|c|c|c|}
\hline & Estimate & Std. Error & t value & $\operatorname{Pr}(>|t|)$ \\
\hline (Intercept) & -220.58237 & 169.88579 & -1.298 & 0.2012 \\
\hline Curah Hujan & -0.03533 & 0.09676 & -0.365 & 0.7168 \\
\hline KecepatanAngin & -0.25782 & 0.74906 & -0.344 & 0.7324 \\
\hline Kelembaban & 1.40929 & 0.84599 & 1.666 & 0.1032 \\
\hline Lama Penyinaran & -1.63697 & 0.62532 & -2.618 & $0.0123 *$ \\
\hline Suhu Rata-rata & 5.93648 & 3.88955 & 1.526 & 0.1344 \\
\hline
\end{tabular}

Hasil pengamatan harian menunjukkan bahwa pada lama penyinaran yang rendah, jumlah rangkum bunga yang tumbuh tetap tinggi dengan jarak penanaman 1.5 x1.5 m dan 1.5 x $2 \mathrm{~m}$ (korelasi= -0.473 dan -0.450). Sedangkan pada jarak penanaman $1,5 \times 1 \mathrm{~m}$ jumlah rangkum bunga yang tumbuh relatif merata rendah (korelasi= 0.122). Karbasium dan Soleymani (2015) menyatakan bahwa jarak tanam dapat mempengaruhi penerimaan cahaya matahari oleh stomata sehingga dapat mempengaruhi produktivitas tanaman.

\section{Pengaruh Lingkungan pada Pembentukan Po- long}

Lingkungan yang diamati dalam penelitian ini adalah curah hujan, kecepatan angin, kelembaban, lama penyinaran dan suhu rata-rata harian. Hasil analisis data pada Tabel 2 menunjukkan bahwa pembentukan jumlah polong cenderung dipengaruhi oleh kecepatan angin $(\mathrm{P}>0.1)$.

Hubungan antara kecepatan angin dan pembentukan jumlah polong merupakan hubungan negatif dengan nilai korelasi -0.268 yang berarti bahwa peningkatan kecepatan angin dapat menurunkan pembentukan jumlah polong Indigofera. Penurunan pembentukan jumlah polong yang terkait dengan 

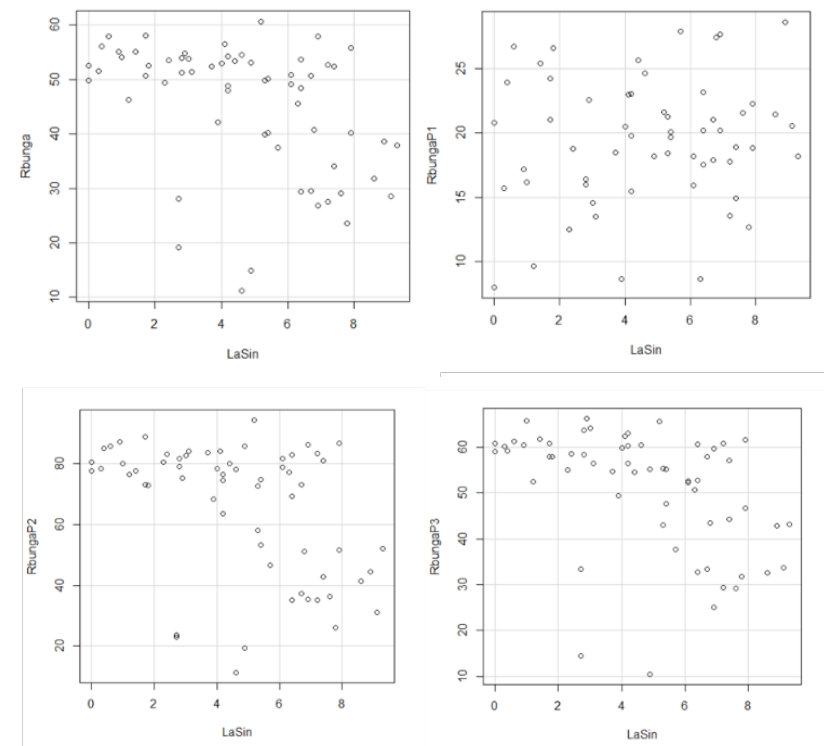

Gambar 3. Diagram Pencar Pertumbuhan Rangkum Bunga Indigofera Selama Pengamatan pada Jumlah Rangkum Bunga Keseluruhan, Rangkum Bunga yang Ditanam pada Jarak 1 X $1.5 \mathrm{M}, 1.5 \times 1.5 \mathrm{M}$ Dan $2 \times 1.5 \mathrm{M}$

kecepatan angin diduga terkait dengan rangkum bunga Indigofera yang mengalami kerontokan pada saat angin besar sehingga pembentukan polong dari rangkum bunga mengalami kegagalan. Menurut Tucker (2003), pembentukan polong pada tanaman legum sangat tergantung pada kesempurnaan organ pada saat fase pembungaan.

Tabel 2. Uji Pengaruh Lingkungan pada Pembentukan Jumlah Polong

\begin{tabular}{|c|c|c|c|c|}
\hline & Sum Sq & Mean Sq & F value & $\operatorname{Pr}(>\mathrm{F})$ \\
\hline (Intercept) & 76.644705 & 88.861914 & 0.863 & 0.3946 \\
\hline Curah Hujan & 0.001597 & 0.049525 & 0.032 & 0.9745 \\
\hline KecepatanAngin & -0.768290 & 0.377897 & -2.033 & 0.0502 . \\
\hline Kelembaban & -0.505913 & 0.436792 & -1.158 & 0.2551 \\
\hline Lama Penyinaran & 0.063263 & 0.326069 & 0.194 & 0.8474 \\
\hline Suhu Rata-rata & -0.716511 & 2.052183 & -0.349 & 0.7292 \\
\hline
\end{tabular}

Signif. codes: 0 (***) $0.001^{\prime * * \prime} 0.01^{\prime * \prime} 0.05$ " 0.1 “'1

\section{SIMPULAN}

Faktor lingkungan mempengaruhi yang dapat mempengaruhi pembentukan rangkum bunga Indigofera adalah lama waktu penyinaran matahari. Sedangkan pembentukan polong cenderung dipengaruhi kecepatan angin rata-rata yang terjadi di area penelitian.

\section{DAFTAR PUSTAKA}

Abdullah, L. 2010. Herbage production and quality of shrub Indigofera treated by different concentration of foliar fertilizer. Media Peternakan. 33 (3): 169-175

Abdullah, L. 2014. Prospektif agronomi dan ekofisiologi Indigofera zollingeriana sebagai tanaman penghasil hijauan pakan berkualitas tinggi. Pastura. 3 (2): 79-83

Abdullah, L. \& Suharlina. 2010. Herbage yield and quality of two vegetative parts of Indigofera at different time of first regrowth defoliation. Media Peternakan. 33:44-49

Buechling, A., P. H. Martin, C. D. Canham, W. D. Shepperd \& M. A. Battaglia. 2016. Climate drivers of seed production in Piceaen gelmannii and response to warming temperatures in the southern Rocky Mountains. Journal of Ecology. 104: 1051-1062

Herrera-C, F., W. R. Ocumpaug., J. A. Ortega-S., J. Lloyd-Reilley, G. A. Rasmussen \& S. Maher. 2008. Environmental Influences on Seed Quality of Wind mill grass Ecotypes in South Texas. Agronomy Journal. 100 (4): 1205-1210

Jahan, S., A. G. Sarwar \& M. S. A. Fakir. 2013. Phenology, floral morphology and seed yield in Indigofera tinctoria $\mathrm{L}$. and I. suffruticosa Mill. Bangladesh Journal of Botany. 42 (2): 231-237

Karbasium, A. \& A. Soleymani. 2015. Effect of planting density and row spacing on light extinction coefficient, light interception and grain yield of corn (single cross704) in Esfahan. Research Journal of Fisheries and Hydrobiology. 10 (9): 146-152

Kumar, P. R., S. K. Yadav, S. R. Sharma, S. K. Lal \& D. N. Jha. 2009. Impact of climate change on seed production of cabbage in North Western Himalayas. World Journal of Agricultural Sciences. 5 (1): 18-26

Łabuda, H. \& A. Brodaczewska. 2007. The influence of environmental factors on flowering of French Bean (Phaseolus vulgaris L.). Acta Agrobotanica. 60 (2): 153-159

Purcell, L. C., M. Salmeron \& L. Ashlock. Soybean Growth and Development. Chapter 2. Soybean Production Handbook. Division of Agriculture Research and Extension. University of Arkansas System. US

Tucker, S. C. 2003. Floral Development in Legumes. Plant Physiology. 131: 911-926

Villa campa, Y., A. Confalone, M. Cortes, B. RuizNogueira \& F. Sau. 2009. Modelling the effect of temperature and photoperiod on the faba bean (Vicia faba L.). WIT Transactions on Ecology and the Environment. 122: 53-59 